DOI: https://doi.org/10.3126/njdrs.v18i01.41945

\title{
Interface between Tourism and Rural Development in Panchmul, Nepal
}

\author{
Rajan Binayek Pasa, PhD \\ Lecturer at Central Department of Rural Development \\ Tribhuvan University, Nepal \\ Email: rajan.pasa@cdrd.tu.edu.np, ORCID: https://orcid.org/0000-0001-8886-7714
}

\begin{abstract}
This study explores interfaces between tourism and rural development outcomes (constructs) in Panchmul located in Aandhikhola rural municipality of Syangja District. A comprehensive researcher strategy has been applied in this study. The necessary information was collected from 21 participants selected purposively from tourism and rural development programs. This study found functional interfaces or two ways contributions between tourism and rural development outcomes. Similarly, tourism related activities are building social capital, developing rural infrastructures, maintaining community well-being, and conserving biodiversity which are learning platforms to the neighboring villagers and others people. Panchmul can be a model village for rural development if skillful local youths are mobilized in the activities of tourism development, promotional, and management. That's why there must be transformative interfaces between constructs thus better to apply the strategic interface model developed from this study by the local development stakeholders.
\end{abstract}

Key words: Interface, tourism, agriculture, rural development outcomes, Panchmul, homestay

\section{Background}

Rural development is a process, phenomenon, and discipline that encompass agriculture development and allied activities, village industries, crafts, and socio-economic infrastructures as well as in rural areas (Singh, 1999; Singh, 2009). It aims for improving the livelihood of rural people through better access to natural, physical, human, technological, financial, and social capital equally (Atchoarena, 2003). Rural development process seeks to alleviate poverty, mass utilization of resources, commercialization of agriculture, food security, creating opportunities, infrastructural development of the rural community, and modernization of the society (Chaudhary \& Pasa, 2015). In practice, there are minimum employment opportunities in rural areas. Most of the small and cottage industries are established in urban centers. Total 6,328 industries have been registered by mid-March, 2016. More than NRs. 10.84 billion has been invested in those industries thereby generating employment for 512,159 people (MoF, 2016). Around 36, 19, 41 Nepalese youths (339138 males\& 22803 females) were involved in foreign employment in the fiscal year 2018/19 among them which 1.5 percent were skilled, 23 percent semi-skilled and 75.5 percent unskilled (MoF, 2019).

The development planning has long been subverted to serve the political and economic interest of a small class of Nepali elites (Shrestha, 2009, p. 71). Shrestha blamed that instead of creating a new, progressive social order and a good society where everybody could enjoy life, the development planning has legitimized only the authority of the ruling elites, thereby propagating the socio-economic disparities. Other scholars also have similar opinion like Shrestha. For example, Panday (1999) mentioned that in the name of foreign aid, the government has been mounting per head NRs 24,000 credit capital that is increased into NRs 28963 in FY 2017/18 (MoF, 2017/18). Pandey came to the understanding that development fails "when planning and development become a bureaucratic ritual at the service of 
dominant interests at the center as opposed to needs of the districts/rural communities" (Pandey, 1999, p. 102). Reasoning that 80 percent of the Nepali are living with poor networking of infrastructures and subsistence-based farming practices (CBS, 2012). Economically, Nepal is regarded as 'Least Developing Countries' with its per capita income 1,048 US\$ (at nominal GDP/PPP) and the population living below the poverty line is 18.7 percent $(\mathrm{MoF}, 2019)$. The Gini coefficient of income inequality in fiscal years $1995 / 96$ was 0.322 ( 0.426 for urban \& 0.308 for rural areas) that has mounted by 0.328 ( 0.353 for urban $\& 0.311$ for rural areas) in the fiscal year 2010/11 (CBS, 2019). After the massive earthquake in April 2015 , the economic growth rate of country is lowered at 0.5 percent in $2015 / 16$ and was nurtured by the reconstruction efforts and average growth during 2016/17-2018/19 by 6.95 percent (ADB, 2019). Likewise, the share of the working-age population (15+ years) to the total population is 71.5 percent including 55.6 percent females. The overall unemployment rate in the country is 11.4 percent and the unemployment rate for females is 13.1 percent (CBS, 2019). It might be the reason that the government of Nepal has identified tourism as the lead sector of the economy and tourism can be an alternative for rural development.

Tourism represents a journey of tourists for making entertainment through various activities within a short period (WTO, 2018). Nepal is known as an important tourist destination in the world due to its natural beauty like; gorgeous mountains, rivers, waterfalls, lakes, green forests, caves, natural sceneries, panoramic landscapes, and rare flora and fauna (Kunwar, 2006). A splendid array of mystique natural as well as cultural heritage is the major product of Nepalese tourism attractions (Joshi, 2008, p. 130). The World Travel and Tourism Council estimates that the tourism sector now accounts for 9.5 percent of global GDP, 7.6 trillion US\$, and 313 million US\$ directly and indirectly jobs were created in 2017 (WTO, 2018). In Nepal, 11, 72073 international tourists visited in 2018 that contributed 7.5 percent to the GDP (NRs 2.876 billion) and also created employment for the 427,000 people (NTB, 2019). The contribution of the tourism sector to GDP is targeted to contribute by 9.29 percent by 2025 (MoCTCA, 2017). However, it is difficult to achieve proposed goals/targets with the current level of investment and infrastructure in the tourism sector which fails to promote rural tourism. Globally, the last 25 years have seen massive growth in active countryside tourism to experience rurality as an alternative to the perceived pressures and constraints of urban life (Costa \& Chalip, 2005). Following this, a pro-poor tourism strategy is implemented for sharing tourism benefits to the marginalized people (Hall, 2007) at the community level to cope with socio-economic and environmental issues (Richards, 2009) or rural development issues.

In this background, in developed countries, tourism is considered largest growth industry with no sign of slowing over the long term (WTO, 1998; 2010). For example, since 1980, tourism has increased worldwide by an average of 9 percent annually, reaching 940 million in 2010 and is expected to grow to nearly 1.6 billion by the year 2020 (WTO, 2015). Moreover, tourism employs over 235 million people across the world, directly supporting 412,500 jobs and indirectly supporting 952,500 jobs (Tourism Bureau Statistics [TBS], 2012). Tourism has been creating 945000 employments (39th position in global rank) and contributed 6.2 percent on GDP (43rd position in global rank) in the world out of all the economic sectors (WTTC, 2017).

In case of Nepal, monetized and income-based rural tourism was considered lately though saints, intellectuals, and interested travelers used to move around for learning and entertainment. Sirubari village of Syangja was the first rural tourism destination in Nepal (Upadhyay, 2008) but nowadays it has been picked up in many potential rural areas of the country. Tenth Plan (2002-2007) has capitalized on Nepal's attractive natural beauty, unique culture, and heritage in the Tourism for Rural Poverty Alleviation Program (TRPAP, 2004, 2006b). It was launched in September 2001 under the Ministry of Culture, Tourism, and Civil Aviation with technical/financial assistance from UNDP, DFID, and SNV Nepal. The pilot sites were Dolpa, Lumbini, Chitwan, Rasuwa, Solukhumbu, and Taplejung Districts. And it had covered and 28337 households of 48 VDCs and benefitted the 1,60,732 local people. TRPAP improved the livelihood of rural poor and disadvantaged groups of people and empowering to 50 percent of females 
participating in this program. TRPAP also helped to develop 15 years Tourism Marketing Strategic Plan (2005-2020) for national-level tourism marketing (NPC, 2002).

During the interim plan (2010-13) Homestay Regulation Guideline 2067 BS (2010) was developed for mobilizing local people in tourism, so that they can generate self-employment opportunities from tourism activities and small-scale industries. The fourteenth Plan (2016-18) came with National Tourism Strategic Plan (2016-25) for promoting rural tourism (NPC, 2016). For the implementation of NTSP federal government has identified 100 new tourism destinations in the country (MocTCA, 2018).

In the federal context, the new constitution (2015) has developed a new course of rural development. It has provisioned a three-tiered government system; federation, 7 provinces, and 753 local levels (CAS, 2015). The structure of the state also has provisioned jurisdiction lists to the federation (33), provinces (21), and local levels (22). Even there is provision to use of fiscal power and distributions of sources of revenue between/among devolved governments through the cooperation, coordination, and collaboration to achieve common national goals [1] (MoFAGA, 2018). For this purpose, the federal government has been changed the organizational structure at local levels and also has been planned to reform of administrative capacity and capability of the human resources. Accordingly, High-level Administration Reform and Monitoring Report, 2016 recommended the government to mobilize a maximum of 350 to a minimum of 60 such resources in each local for effective implementation of 22 devolved jurisdictions (MoFAGA, 2017). Owing to study, there is provision to develop one tourism destination at each local level just for bringing economic prosperity through tourism.

Finally, on one hand, beyond doubt rural development is possible with transformative interfaces between tourism and rural development outcomes. Even these two constructs are now recognizing similar intervention principles such as focusing on rural poverty alleviation, emphasizing community participation, and gender issues (TRPAP, 2006; NPC, 2016). In another hand, it is where Inchon Declaration (Education Framework 2030), suggested educators conduct transformative research agendas for transforming the daily life activities of the rural people (UNESCO, 2016). However, the interfaces between tourism and rural development have not yet been well discussed in Nepali academia (Pasa, 2019). In this respect, it is inevitable to appraise interfaces [2] between tourism and rural development that helps to develop a strategic interface model for performing two ways contributions between constructs. This study thus tried to explore interfaces between tourism and rural development as well as two ways contributions of tourism and rural development outcomes performing in Panchmul area located in Aandhikhola rural municipality of Syangja District.

\section{Methodology}

This study applied multiple case study methodology (comprehensive researcher strategy) that helped to understand contextual historical and cultural settings of the participants (Denzin \& Lincoln, 2011). That is inevitable for understanding multiple cases through detailed in-depth data collection and linking causes and outcomes of the studied constructs tourism and rural development (Yazan, 2015). The case groups have stressed developmental factors evolving concerning bounded time and environment (Flyvbjerg, 2011). Therefore, I purposively selected 21 articulating case groups/participants (i.e. 9 from tourism program $[\mathrm{T}] \& 12$ from rural development program [RD]) for generating narrative information. The maximal purposive sampling method was applied to establish diverse variation so that findings can increase the likelihood (Creswell, 2007, p. 216). Diverse variations were established by following four aspects of sampling; event [single place; Panchmul area], setting [different socio-cultural contexts], artifacts [manmade objects], and actors [local development stakeholders [3] (Creswell, 2009). The required primary information was generated through observation and in-depth interviews [INT]. An indepth interview guideline was prepared based on nine themes: knowledge and professional skills on tourism; perception on rural development activities; perceptions on indigenous knowledge; outcomes of homestay tourism at the community level; forest resource management practices; challenges of tourism development; challenges of youth drain and mitigation measures; use of vocational training in homestay 
tourism; the advisory role of educated individuals in tourism and rural development activities. Likewise, an observation checklist was developed for understanding out-migration of educated youths; family migration from the village; involvement of educated youths in tourism; involvement of educated youths in rural development; challenges of tourism; challenges of rural development; potentiality of tourism development and prospects of rural development. The collected information was appraised by applying thematizing, description, direct interpretation, generating patterns, and holistic analysis (Yin, 2013). Besides, the themes of the study (see in Figure 1) were appraised through Bourdieu's theory of practice, Amartya Sen's theory of human capability, and the UN's sustainability approach to development.

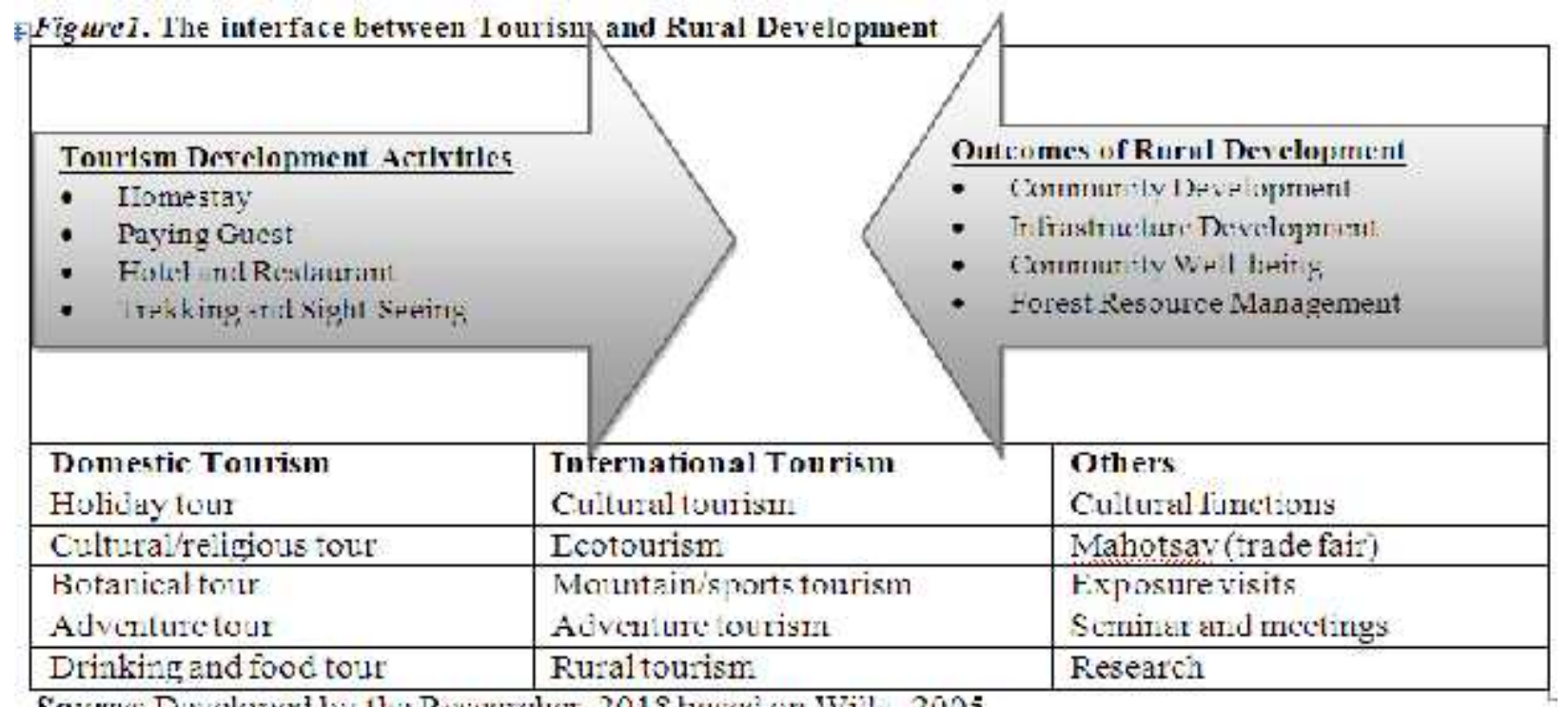

Sanre: Develuyed by the Restedrcher, 2018 basecion Wils, 2005

\section{The Findings: Contextualization of the Constructs}

Panchmul [4] Village Development Committee (PVDC) (before federal structure), presently situated in two rural municipalities (i. e. Aandhikhola \& Arjun Chaupari) in Syangja District of Gandaki Province. Out of nine wards, ward numbers 1, 2, 4, 5, 6, 8, and 9 are located in Aandhikhola while ward numbers, 3 and 7 of Panchmul are presently located in ward number 6 of Arjun Chaupari. The Aandhikhola is formed by merging Aandhikhola, Phaparthum, Setidhoban, Banging Deurali, Bichari Chautra, Chilaunebas, and Panchmul (except $3 \& 7$ Wards) VDCs. The total population of Aandhikhola rural municipality is 25554 (12319 females and13235 males) with 4070 households (ARM, 2017). Panchmul is 24 Kilometers far from district headquarter PutaliBazzar locating in between $83^{\circ} 45^{\prime \prime}$ to $83^{\circ}$ $47^{\prime \prime}$ Eastern longitude and $28^{\circ} 45^{\prime \prime}$ to $28^{\circ} 8^{\prime \prime}$ Northern latitude. The yearly rainfall of the village is recorded up to $3947.8 \mathrm{ml}$ and temperature recorded up to a minimum of $6^{\circ} \mathrm{C}$ to a maximum of $32.4^{\circ} \mathrm{C}$ (PVDC, 2016).

Tourism. The 37 lakes/ponds, 2162.99 hector forest land of 44 community forestry and 5775.73 hector Panchase conserved forest, 54 religious sites, 15 different caste/ethnic groups of different religions (including Hindu, Buddhist, Christian, and Muslim), and annual celebrations of 30 festivals are major natural, religious and cultural attractions of Aandhikhola rural municipality (ARM, 2017). The major tourist destinations such as Dahare Deurali, ThumroJuro, Gorujure, Maidan Kharka, and Sirubari homestay are located in Panchmul (Table 1). Sirubari homestay was started in 1997 in Gurung village [5] by former Captain Rudra Man Gurung (X Indian Army). There are total 146 households including the Dalits in the majority (i. e. 40 Kami, 29 Damai\& 13 Sarki) followed by

Crouched in between the hills A village calls to its guests Himalaya visible from north sides Tourists come to spend their days Tourism \& agriculture can bring change

This village is the example

Learn other villages

See the transformations

Stop your sons and daughters

From moving away

Development is possible

In this rural land 
indigenous groups (i. e. 58 Gurung \& 4 Gharti), and 2 belong to the upper caste i. e. Brahmin). The total population of thevillage was 1137 including 680 females and 480 males.It was located at an altitude of 1700 masl (attitudinally, the area ranges from $1250 \mathrm{~m}$ to $2003 \mathrm{~m}$ ) (PVDC, 2015). Sirubari won a national youth award in 1993, the Pacific Asia Travel Association Gold award in the Heritage category in 2001, and International Mountain Development Prize on International Mountain Day 2004 (Upadhyay, 2008).

Rural Development. Rural development activities in Panchmul still becoming a key issue of local development stakeholders though the status of economic, agricultural, socio-cultural, and environmental development activities are satisfactory as compared to other local levels located in hilly regions. Economically, local people are involved in diversified livelihood activities (tourism, business, government and private jobs, foreign employment, and agriculture) for sustaining family livelihood. However, local development stakeholders are giving high priority to tourism and agriculture development. Panchmul has 878.88 hectares of agricultural land located in slope geographical areas. The village has a huge amount of terrain and pasture lands in northern parts that are suitable for animal husbandry. The agriculture contact center of Arjun Chaupari established in 1981 has been providing financial and technical support to the farmers. The center has fifty-five farmer groups and provides Integrated Pest Management and Integrated Crop Management pieces of training and exposure visit programs to the farmers. Further, the center also has been providing agricultural inputs (seeds, breeds, plants, pesticides, insecticide) and modern technologies (tunnel farming, tractor, thresher, and modern box for beekeeping) support along the technical knowledge and skills to the farmers. Panchmul village is a pocket area for wheat, maize, and millets. Farmers are also producing rice, potato, millet, mustard, and pulses.

Socio-culturally, Brahmin, Dalits, Gurung ethnic groups, and Muslim religious groups are living with a mutual relationship. There is we-feeling and community sentiment among the groups that are building social capital. However, Gurung culture is more famous and popular in the village. Gurung is Mongolian in terms of race.Majorities of them follow Buddhism as their religious belief. They perform traditional songs (Rodi), and dances during festivals. But in recent days, young generations are practicing Rodi culture in modern ways of celebration. Dalit people also celebrate festivals according to Hindu culture. Dashain, Tihar, Makar Shakranti, Buddha Jayanti are common festivals. Muslims celebrate Ramadan and Eid. Similarly, villagers are becoming members of different types of social, cultural and economic, and environmental organizations for transforming socio-cultural and economic structures. Some organizations are also advocating for the mobilization of natural resources.

Panchmul is rich in forest resources consists of subtropical, deciduous, coniferous vegetation with some herbs that have medicinal value. A total of 2222 hector forest land (i.e. 1500 hector government, 708 hectares of community, and 14 hector religious forests) is benefited to the 1073 households (PVDC, 2016). The beneficiary households are applying their indigenous knowledge for preserving and conserving biodiversity. Majorities of the households (88.52 percent) are still using firewood as fuel (PVDC, 2016). Thus forest management committees are implementing certain rules for collecting firewood from the user groups.

\section{Interface: Rural Development through Community Development}

Rural development is one of the major outcomes of tourism development in Sirubari. I appraised rural development outcomes within limited boundaries or micro levels that focused on empowering Dalits [7] and Gurung communities who are sharing a mixed type of settlements along with few Brahmins in Panchmul. The people are living with a sense of belongingness, community sentiment, and mutual relationships. However, study shows that the Dalits have a low social or ritual status. They are severely attached to the Hindu Varna notion and a hierarchy of purity and impurity. Their daily lives are still largely shaped by caste and particularly by their ritual and economic relationships with the high castes (BK, 2013). National Dalits Commission also defines 'Dalits' as "those communities who by atrocities of caste-based discrimination and untouchability, are most backward in socio-economic, educational, 
political and religious fields, and deprived of human dignity/social justice" (NDC, 2008, p. 22). In some places, they have converted their religions, but they have rarely been able to escape the stigma of their formal position in the Hindu caste hierarchy is the question to all (Bennett et al., 2013).

In the case of my study locations, the Dalits (Bishowkarma, Pariyar, Darji, Sarki, and Sunar) population is 2159 out of 4601 total population that is 46.92 percent. The literacy rate of Dalits (6 years \&above) is 52.4 percent compared to the national average of 65.9 percent (NNDSWO, 2015). However, in my study location, literacy rate of Dalits has reached 100 percent and some Dalits youths are also completed higher-level education. The Human developments Index (HDI) of the Dalits (0.434) is the lowest in Nepal (national average 0.541). In my study, caste/ethnic-wise rural municipality the HDI of different caste and the ethnic groups are different, including Brahmin (0.557), Janjati (0.509), and Dalits (0.446) (NPC, 2014).

Similarly, Dalits have poor representation in the civil service of the government i. e. only 1.94 percent whereas it is 62.58 percent, 19.55 percent and15.93 percent for Brahman/Chhetri, Indigenous nationalities, and Madhesi respectively (NNDSWO, 2015). But in my study location, 32 Dalits are pension holders within the retirement from Indian Army and Police services. 78 Dalits youths are joining in government jobs. Among them, 42 youths are Indian Army, 17 youths are in Nepal Army/Polices, 11 youths are teachers and 8 youths are bureaucrats $(\mathrm{H}$. L. Nepali, Personal communication in cell phone, Tuesday, August 21, 2018). Eventually, the trend of preparing public service commission exam and for Army Police selection test is increasingly becoming popular among the Dalits youths due to Dalits reservation quotas as per the constitutional provision.

In this respect, tourism activities in Sirubari have in/directly contributed to community development around Sirubari villages. There are fifty plus rural tourism destinations located in the Western region including Sirubari that earn more than NRs. 51, 00000 annually from homestay tourism (U. Gurung, 18 October 2019 [INT/T]). For a decade, several Nepalese people have been visiting to experience homestay activities. Hosts are fostering community sentiment among themselves and social capital with the guests, development experts, politicians, bureaucrats, and researchers. My research participant, a member of the Tourism Development and Management Committee (TDMC) said,

Without group efforts, it is impossible to run homestay. Mostly, guests are notified and booked staying nights before a week of their travel time. We members of TDMC working voluntarily (not in a salary basis like others) make a schedule for a welcome program conducted in three different entrance of the village. Dalits people play traditional music [Panche Baja] and members of the Mother Group serve garland to the guests. Guests enjoy our welcome and cultural program. Then we serve welcome drinks and light snacks in Buddha Gumba with continuous traditional music. After that host member took them to their home (R. Gurung, June 8th, 2016 [INT/T]).

These quotations above imply the importance of community organization for fostering social capital. The social benefit of tourism raises quality of life, promotes community pride, enhances gender and age equality, and builds capacity for community organizations (REST, 2003). My research participants also said that their collective efforts became an unavoidable means for development of tourism in the initial phase but at present, it is becoming the end of community development. They are thus now applying participatory development and ethical leadership styles. Accordingly, another member of TDMC said,

Our Gurung culture is very supportive to all. In the past, Dalits' settlement was untidy/unmanaged like a slum area. Their life was vulnerable. Later on, they were involved in homestay services for playing traditional music. Some of them worked as porters and wage laborer. They are now producing sufficient crops from our rented land. Dalits youths are joining in Army and foreign employment with our technical and financial support. Now they invest their income in child education and income generation activities. They bear good planning to offer homestay in their village (L. J. Gurung, June 6th, 2016 [INT/T]).

Nepalese Journal of Development and Rural Studies, Volume, 18, 2021 
L. J. Gurung's claim signifies the transformative role of cultural capital that has been transforming the livelihoods of Dalits. It has also yielded cultural benefits of tourism that can encourage respect for a different culture, foster cultural exchanges, and social support systems, and embed development in local culture (REST, 2003). Mr. Gurung further argued that Dalits have now become more interactive and empowered and transforming life and livelihood. During my interaction, an aged Dalits shared that he frequently visits Kirtipur, Kathmandu to meet Prof. Ganeshman Gurung and Ratna Gurung who are playing advisory and networking roles to the villagers at local levels (T. B. Pariyar, personal communication, June 8, 2016). I can say that there is a supporting and mutual relationship among Dalits and Gurung people. Supporting this, the head member of Sirubari Baja Pati expressed that,

Dalits are realizing the importance of group participation in homestay. We can also learn various life skills and earning opportunities from tourism activities. We maintain our surrounding neat and clean after tourism development. We also motivate our children to complete secondary education. Because of education, they are now involved in different sectors. Some of them have joined government jobs in the Indian and Nepalese Army and tend to go for foreign employment with the moral and financial support of Gurung. Indeed, our living status has been improved due to homestay and remittance (T. P. Darji, June 7th, 2016 [INT/T]). Further, he added,

I verbally circulate public information among the villagers throughout the village. My grandfather first followed this occupation by visiting them and asking personally. It was suitable in the past. At present, there is a cell phone with every individual but we are continuing the same practice as like of grandfather. For me, this typical practice sometimes provides an interesting experience to the guests. Through this occupation, I can establish good relationships with Gurungs. I can occupy their land at a cheap rent and produce sufficient food grains. I am satisfied with my duty but I could not compel my sons to follow this occupation. I hope anyone's son will follow this profession after my death (T. P. Darji, June 7th, 2016 [INT/T]).

Mr. Darji's sayings signify about learning opportunities of the Dalits people from tourism activities. It shows that the educational benefits of tourism can promote the acquisition of new job skills, create new professions in the village, and encourage the use of new knowledge and cross-fertilization of ideas with other cultures and mutual respect (REST, 2003). Accordingly, my participant said, Dalits people are learning daily life skills, communicative skills with guests. Dalits women and children have become more interactive and maintain their education, health, and hygiene. For him, these are major outcomes of tourism activities. I also, found that Dalits were now investing in child's education and higher education for youth empowerment. Let me report saying of chairman of Sopal Samuha [8] living in Kathmandu,

There are 200 members and 21 executive members in Sopal Samuha. The goal of the organization is to maintain unity among the Gurung people and preserve religious and cultural norms and values, rituals, and rights. This organization conducts a picnic program annually. We also collect funds for helping our members during their death ceremony. We also published a bulletin to report organizational activities. This organization has been allocating funds for social development activities in our villages (R. K. Gurung, 2069 [DA]).

The above description implies that the importance of ethno-development for rural prosperity. As also stated in an earlier discussion, there are four foundations for ethno-development, including territorialism, internal self-determination, cultural pluralism, and ecological sustainability (Hettne, 1996). Reflecting upon those elements, their cultural institution is not only establishing a mutual relationship and we feeling among Gurung but equally investing in Dalit community and whole Panchmul for maintaining community infrastructure. At the same time, members can get financial support from Sopal Samuha. This support has also empowered Dalit communities both directly and indirectly for many years.

\section{Tourism for Physical Infrastructure Development}

Nepalese Journal of Development and Rural Studies, Volume, 18, 2021 
Tourism generates independent funds for community development, creates employment in tourism, and increases household income (REST, 2003). In Sirubari, households involved in tourism are collecting basket funds from their earnings for infrastructure development. I wanted to understand how Sirubari homestay is supporting to implementation of public service infrastructure development projects. My participants expressed that,

Sirubari homestay, selected as one of the hundred new tourism destinations of the country received NPR. 10,00,000.00 grants from Gandaki Province and constructed a hall nearby picnic spot,upside the village. The central government also allocated NPR. 80,00,000.00 grants for constructing a two-story building nearby the southern entrance gate of Sirubari homestay. Our Deurali homestay also received NPR. 10, 00,000.00 from Province and constructed an entrance gate nearby Siruabri-Bhakimle roadside, maintained community building, and constructed twometer wide and 300-meter long foot trials towards Dahare Deurali temple. We also received NPR. 2, 00,000.00 from the pond conservation office, Parbat for maintenance of Dhuli and Sani Dahas. For the same purpose provincial government also going to allocate NPR. 10, 00,000.00 (C. M. Poudel, personal communication, Thursday 20th August 2019).

These descriptions of what L. J. Gurung said to me imply the importance of public grants for community infrastructure development projects. The economic benefits of tourism can generate independent funds for community development, create employment in tourism, and increase household income (REST, 2003). Reflecting on next participant, the tourism sector is becoming a priority sector of federal governments as the trend of investing in tourism infrastructures development projects is increasing. In the fiscal year 2018-19, Ministry of Industry, Tourism, Forest, and Environment of Gandaki province allocated NRs. 300 million and allocated per NRs. 10, 00000 grants to the 190 community homestay moving homestay. Another local intellectual from Bhakimle said,

Last year Parbat district allocated NPR. 9, 0000.00 for constructing a Vedic school in Dahare Deurali Temple premises. This year we also got a drinking water project from the central level. This project collects drinking water from 390 meters down the surface from the temple site. It may cost more than ten million (NPR)according to tentative estimation of the technicians. We are planning to set nine taps nearby the temple (C. P. Poudel, personal communication, December 1, 2016).

This description reported by local intellectuals implies government efforts on physical infrastructure development. UN sustainability approach also advocated that the physical capital building process is more essential for sustainable tourism development (Hada, 2007). According to him, government fund has been allocated for infrastructure development projects for religious identity. Vedic school can become an attraction to the guests. In the ancient period, five years old children must read Vedain Gurukul [9]. They spent 25 years in Vedic schools. They allowed enjoying with marital life after twenty-five to fifty. They spent nomadic life after fifty to seventy-five years and finally spent spiritual life after seventy-five to hundred years (Swami, 2016). This might be the reason, the popularity of Vedic and Sanskrit education has been increasing in Nepal. In this context, this place can be a hub for Vedic tourism too. Another local youth from Majhkateri said,

Local intellectuals from Darau have constructed the Siddha baba temple, storeroom, picnic point, and view tower in Hile Danda. Sopal Samauha provided funds to build those infrastructures. Mountain range and rural settlements and greenery of jungle areas can be observed from that peak. It is located nearby the trekking route of the Sirubari village. At the same time, local students and youths also visit that area for a picnic. The visiting and traveling behavior of the students and local youths have been increasing yearly because of the impact of tourism activities in Sirubari village (J. B. Gurung, personal communication, November 4, 2016).

J. B. Gurung's description implies a demonstrative effect of Sirubari homestay that is motivating neighboring villagers. Having higher multiplier effects and minimal capital investment, tourism can generate tangible benefits where traditional livelihoods are under stress (Hoermann \&Kollmair, 2010). 
Owing to that neighboring villagers of Sirubari are planning to mobilize their traditional culture and offer homestay services. Some of them have constructed view towers and physical infrastructures. At the same time, visiting and hiking trend of local students is increasing. My participants, politician from Panchmul expressed,

Sirubari homestay not only provides earning and learning opportunities to the villagers but also contributes to rural infrastructure development. We were in the dark phase before tourism development. We got electricity. Our village is also connected with road accessibilities on east and west sides. After the development of the road, farmers are also supplying local products in market centers. Some educated persons are migrating from the village. They will return, if the government gives worth value to educated people (J. N. Dhakal, August 29th, 2016 [INT/RD]).

In this regard, another participant added,

We are proud to be neighbors of Sirubari. Homestay tourism has changed the overall development status at the local level. We got electricity, road and health facilities for many years. We [villagers from Panchmul] must express our gratitude to former Captain Rudraman Gurung who started homestay tourism. Dr. Ganesman Gurung and Chndraman Gurung (members of Constituent Assembly born in the same village) contributed a lot to infrastructure development. Recently Prof. Ganesman Gurung took initiation for constructing foot trials to reach hilly ranges from two different locations (J. P. Chapagain, June 7th, 2016 [INT/E]).

The above descriptions highlight the contributions of Sirubari homestay for developing public service infrastructures around Panchmul. UN sustainability approach also advocated that the physical capital building process is more essential for sustainable development (Hada, 2007). Owing to that local politicians belonging to Sirubari and neighboring villages played the productive role to implement infrastructure development projects that have been providing services and facilities to the villagers. Even the government is providing infrastructure development projects because of the global identity of Sirubari homestay. Let me report about the project that is implemented by Nepal Tourism Board. In the same theme, role model entrepreneur from Rajswora expressed,

Sirubari homestay started in 1992. In the early stage, they used solar energy. In 1996 they collected NPR 23,00000.00 for electricity. Their effort became national news that I heard during my childhood. After six years each household of this village collected NPR 5000.00 and worked voluntarily for electricity. The government provided two transmitters and 10 steel poles $(\mathrm{P}$. Bagale, personal communication, December 3, 2016).

Further, he said that,

Again all the households collected community funds for road accessibility. The first road track opened from SetiDovan to Bayale. We joined Bayale to Panchmul, a six-kilometer distance. The second track opened from SetiDovan to Bejhang. We collected NPR 35, 00000.00 for connecting Bejhang and Panchkula. This track is going blacktopped in this fiscal year. Politicians came to Seti Dovan on November 28th for shilanays. The third road track opened from Darau to Panchmul. This track has also granted a budget for the blacktop in this fiscal year (P. Bagale, personal communication, December 3, 2016).

These descriptions are the evidences ofthe importance of community participation in maintaining public service delivery networking. Once rural communities mobilized local resources then members of the community become both beneficiaries and important actors for transforming rural space (UNESCO, 2003). Accordingly, my participant reflected a lesson learned from Sirubari, as his father and relatives had also played an active role in building public infrastructures. No doubt, community participation is essential for infrastructure development projects at local levels. However, most of the local people are not yet realizing their responsibility. Further, a head teacher of the community school of Sirubari said,

There are 105 students and 10 teachers in our school. Our school gets 2 corer 56 lakh financial supports for construction of new building in this fiscal year. Our relative (brother) working as a top-level bureaucrat played a networking role for that project. We also started English medium 
class up to the primary level this year. I am playing an advisory role in the tourism development committee, ward nagrik manch, and UNDP program (S. Gurung, June 8th, 2016 [INT/T]).

The above descriptions indicate the importance of the networking in health and educational service delivery. The process of establishing strong power relations within top-level bureaucrats and politicians is called linking social capital (Harpham, Grant \& Thomas, 2002). Owing to that, my participant argued, they are constructing a new school building located nearby the west entrance gate of Sirubari homestay village. Most of the guests visit the school and interact with students.

\section{Tourism and Community Well-being}

Exploring alternative approaches to human progress and well-being, cultural diversity is crucial. By community well-being, I mean transformed livelihoods of the villagers through tourism activities. It takes care of cultural diversity as well. Cultural diversity is humanity's greatest source of creativity and wealth that provides different approaches to solving fundamental aspects of life, natural ecosystem, religion, and spirituality (UNESCO, 2015). Even in Sirubari cultural tourism also has maintained the natural ecosystem, religious activities, and well-being of the local people. My participant, a member of TDMC said,

The tourism committee receives NPR.1,000.00 per person per day from domestic and NPR.15,00.00 from a foreign guest. We collect per person NPR.200.00 extra charges from the group having more than nine guests. The Baja group performs traditional music Panche Baja with folk dance during the welcome program (R. Gurung, June 8th, 2016 [INT/T]).

The above quote implies contributions of homestay service for the economic well-being of the host community including Dalits. The economic benefits of tourism can generate independent funds for community development, create employment in tourism, and increase household income (REST, 2003). Accordingly, hosts and neighbors are getting employment opportunities and increasing household income. I came to know that more than six hundred foreign guests and forty-five hundred Nepali guests have visited Sirubari in 2018 that generating more than NPR. 51,00,000.00 (U. Gurung, 18th October, 2019 [INT/T]). In the same theme, a representative of the local government said,

Sirubari homestay is becoming a learning center for the others. However, because of the poor economy of the villagers, willing to run tourism services could not manage basic infrastructures. We are providing homestay management training and also allocating funds for tourism infrastructure but we do have not a sufficient budget. Our district tourism development and management committee and Nepal Tourism Board should provide technical/financial supports. In doing such several local products including vegetables, fruits, tea, chicken, mutton as well as mineral water can be supplied to the guests (T. P. Rimal, June 7th, 2016 [INT/RD]).

As Mr. Rimal expressed, there is an implication on the role of local government in diffusing tourism activities at the local level. For many years, tourism was considered a magic formula for promoting regional development and reducing poverty in developing countries (Telfer \& Sharpley, 2008). Owing to that after appraisal of the economic impact of rural tourism, local government is now tending to allocate funds for producing tourism entrepreneurs at the local level. In the same line, the next female participant expressed,

Before involving in tourism activities, we were depended on our parents and husbands even for pocket money. At this time, we members of "Mothers Group" are working together for offering homestay services to the inter/national guests and managing our expenditure ourselves. We collect one hundred rupees from each guest. We also charge some amount from our entertainment program that we perform during cultural rituals like; birth ceremony, first feeding of baby, birthday party, marriage ceremony. We also perform a welcome progam for the Lahure who come on annual leave from foreign countries. At this time there is more than four lakh in our basket fund (S. Gurung, June 5th, 2016 [INT/T]). 
This above description signifies the impact of homestay tourism on women's empowerment. In other words, the capabilities of women are increasing and they are playing socio-economic and change agent roles in the community and society. From the perspective of the capability approach, the well-of household is increasing due to tourism and that is foster development in Sirubari (Sen, 1982). They are playing a key role while receiving guests, providing them family environment also conducting cultural programs. In the same line, the head member of Baja Pati from Sirubari expressed that,

Tourism is transforming the livelihood of the Dalits community otherwise we might remain noncivilized. The daily life of Dalits is changing in good way. They are becoming more attractive and interactive. Our social and economic conditions are improving as we are earning from tourism, remittance, wage labor, and agriculture, some are also running local shops. Our children are getting interaction opportunities with inter/national guests. Local intellectuals are also playing a supportive role in for searching employment opportunities for local youths (T. P. Darji, June 7th, 2016 [INT/T]).

Theabove descriptionimplies the importance of homestay tourism for improving the daily lifestyles of Dalits. The economic benefits of tourism can generate independent funds for community development, create employment in tourism and increase household income (REST, 2003). Accordingly, the involvement of Dalits in homestay activities has provided learning and earning opportunities. They are thus, increasing their household sufficiency, economic well-being, and improving daily life through diversified livelihood activities. Similarly, a women activist from Sirubari happily shared that,

We formed married Dalit Buhari's Samauha last year. We conduct entertainment programs during birthday and marriage ceremonies to collect funds. We also conduct such programs while youth employees return village on holiday leave. We want to transform our village ourselves. We are now planning to build a community house for the regular meeting. Thus, we have requested local stakeholders for managing land. We have a further plan of initiating homestay and agro farms collectively. Brahmin farmers are supplying fresh vegetables, chicken, and mushrooms whereas Dalits are supplying pork, buff, and mutton items in homestay village and local market (M. Pariyar, June 7th, 2016 [INT/RD]).

M. Pariyar'sclaim signifies that the motivating role of Sirubari homestay to the Dalit women. My participant belongs to the Brahmin ethnic group has been playing a key role in Sirubari after getting married to Dalit Youth during their school life. She has been working as a coordinator in the ward citizen forum and motivating currently married Dalit women for involving in economic activities. Tourism can promote the acquisition of new job skills, and create new professions in the village (REST, 2003).

Likewise, learning from Gurung Mothers, playing the role of change agent, Dalit women are also willing to play role of change agent in the community. They are planning to invest collective funds in the tourism and agriculture sectors. They could supply their products in homestay destinations. During group discussions, M. Pariyar from Tribeni said that they were supplying vegetables; spinach, beans, cauliflower, and potato, and colorful local cocks and goats in Sirubari (Focus Group Discussion, December 1, 2016). Accordingly, my participant(a hotel entrepreneur of Panchmul) expressed,

My husband passed 8thgrade and I passed $7^{\text {th }}$ in my village when we got married. My husband worked in India for many years. His owner provided him financial support to run some business before seven years. Then we started hotel and restaurant and general store in this hinterland. Our service was started in a rented house. But now within a short period, we became able to buy our plot of land and build our building. We have three rooms and nine beds for the guests and planning to extend (S. Chapagain, August 29th, 2016 [INT/RD]).

S. Chapagain's observation implies the importance of entrepreneurship for economic well-being. According to Bourdieu, money and assets are economic capitals (Thomson, 2008). In the same connection, I understood, because of economic capital gained from India, S. Chapagain became a hotel entrepreneur. According to her, they bought land and built hotel with their earning. This provides a clue 
that homestay has been encouraging others to offer tourism services at the local level. Youth entrepreneur from Rajswora said,

I am supplying my products in Sirubari homestay. Local people including me are in/directly benefited from tourism. Children, students, youth, and aged people have been experiencing tourism activities for many decades. That is the reason at a time we are working together for offering homestay in our village. If so, we can sell our organic products to the guests and we can also supply products outside the village because the condition of the road is going to improve very soon (P. K. Bagale, June 7th, 2016 [INT/RD]).

Bagale implies the economic benefits of homestay activities. For him, the economic benefits of tourism can generate independent funds for community development, create employment in tourism and increase household income (REST, 2003). Bagale has also been experiencing the socio-economic role of tourism service and supplying his products. Hence, he is also planning to mobilize youths in agro-based entrepreneurship, so that they would supply products equally in rural hinterlands and urban centers.

\section{Tourism for Forest Resource Management}

Rural tourism is an alternative form of tourism that has a severe negative impact on destination areas, the environment, and their populations without diminishing the general well-being of the rural people (Eadington \& Smith 1992). In this context, I wanted to appraise, what the negative environmental impacts are caused by homestay tourism in Sirubari. I observed, neat, clean, and green surroundings maintained by the host communities. My participant, a local intellectual expressed that,

Panchmul occupied 2222 hectares of forest lands. Sirubari community forestry occupied 500 hectares won various awards is model in Nepal. The jungle is now becoming a major attraction to the guests. Because of the traditional way of living, farmers are also producing organic products. These are the reasons why guests come to visit Sirubari for observing the jungle, scenic beauty, fresh air, organic foods, and the natural lifestyles of the villagers. But for me, those natural and cultural resources must be mobilized through the country for rural development. For me living in prosperous villages will be so far better than those of unmanaged towns (J. P. Chapagain, June 7th, 2016 [INT/E]).

J. P. Chapagain's saying in the above narration implies the role of community participation in the conservation of forest and land resources in Sirubari. UN sustainability approach also advocated for local resource conservation and mobilization achieving agendas of sustainable development (Hada, 2007). Accordingly, by conservation of forest resources, forest user groups are giving lessons to the neighboring villagers. In other words, the jungle areas are adding more attractions to the guests. Even in the past hosts were provided camping and campfire facilities in jungle sights that provided unique experiences to the guests. Owing to that tourism committee is also planning for providing similar activities to increase the staying days of the guests. But for me, they must start herbal medicine processing and handicraft making center for mobilizing forest products. In the same line, my next participant said,

We are not providing any kind of souvenir to the guests. I am serious on that issue because it is essential. Thus, I am planning to establish a handicraft-making center in the village. The government does not provide any kind of technical suggestions to run cottage industries that could be linked with tourism. Since 2011, we are running a tourism business with self-efforts. Domestic guests reach our village directly. They contact the key person before one week. We provided some brochures in Kathmandu and Pokhara city. Nepal Tourism Board is somehow supporting us by advertising our village in the international market (J. Gurung, December 4th, $2016[$ [NT/T]).

J. Gurung's sayings imply the importance of forest resource mobilization on rural transformation. From the perspective of the UN sustainability approach, the local resource conservation/mobilization process is a must for sustainable development (Hada, 2007). Owing to that J. Gurung wanted to mobilize 
forest resources in several ways and planned to start handicraft making craft industry in the village. My participant, said,

During my childhood, I spent many nights with my grandfather in buffalo sheds. There were more than twenty-five sheds nearby the proposed viewpoint. You can reach there in twenty-five minutes. One household reared more than fifteen buffaloes. In summer, we shifted buffaloes around farming land for fertilizer. We supplied ghee in Pokhara and Butwal for earning. You can also observe that place. You can see plots demarcated by stone walls just the right side from the water pond (T. R. Adhikari, August 28th, 2016 [INT/E]).

T. R. Adhikari signifies the traditional livelihood strategies of local people in Rajswora. From the perspective of the UN sustainability approach, local resource conservation/mobilization is a must for sustainable development (Hada, 2007). Reflecting upon the sustainability approach, in the past local people utilized forest resources for animal husbandry. They supplied crops and dairy products by foot. He blamed, in the name of community forestry, local people compelled to change traditional livelihood with due restrictions for collecting fodder and firewood. But now this location is more potential for agroecotourism. Likewise, the next participant shared,

District Forest Officer suggested we [user groups] demarcate three blocks of government forest that could be major attractions from a greenery point of view. But from an agro-ecotourism point of view, Dalits have more than 1000 Ropani pasture/forest land upside the Sirubari village. This land had provided them in reward for their wage labor when they built Panchmul School in 1930. Dalits need technical/financial support to utilize this land so that they can start a community horticulture farm (C. M. Poudel, personal communication, Thursday 20th August 2019).

C. M. Poudel signifies the importance of tourism development for utilizing private pasture/forest land resources. His views indicate that still, Sirubari homestay failed to supply enough local and organic products to the guests that are must according to Homestay Regulation Guideline 2010. That is why he suggested Dalits perform community-based farms in their private land property.

\section{Two Ways Contributions}

While exploring the interface between tourism and rural development, I found contributions in two ways. One is: Sirubari became a role model Village throughout the country. Villagers use forest resources for tourism development. Neighboring villagers of Sirubari and other Nepalese villagers learned lessons from Sirubari about homestay management and forest resource management. Later the concept of the homestay was also started by other community members throughout the country. Because of the homestay service, Sirubari owned community pride and also established its identity in the national and international tourism market. After involving in tourism services, the Gurung people could not manage time for farming activities. In such a situation, they gave their land to the Dalits on contract farming that helped to increase the family food sufficiency of Dalits. The other is: for sustaining homestay services in the village, the Gurung people gave high priority to the English language. They started to enroll their children in English Medium Boarding schools. To ease it, they started to migratein urban areassuch as Kathmandu, Pokhara, and Syangja. At the same time, because of good relationships with international guests, some Gurung youths started working in Western Countries with attractive salaries. That encourages other youths to work in economically developed counties such as London, Germany, Hong Kong, Korea, and Japan. The trend of rural to urban migration and youth migration to abroad finally made Gurung village with family pillage. Because of it, there are no children to play with guests and neighboring children. There are no female and male youths to perform cultural programs. There are no youths to guide the guest to Thumro Juro for sunshine. However, Dalits youths are becoming institutional members in local youth clubs and also involved in cultural programs. They are getting better earning and learning opportunities by participating in the dance program and leadership role. However, informal, nonformal, and formal education are equally playing a limited transformation role for reciprocal contributions between tourism and rural development within Sirubari Village. In the same line, Pasa (2020) reveals that 
Amaltari Bufferzone Community Homestay around Chitwan National Park also has brought positive impacts in community and social level from a rural development perspective.

\section{Theoretical Reflection}

In this section, I have presented a theoretical reflection on the interface between tourism and rural development. Theoretical perspectives helped me to explore battlefields of knowledge that shape the relations between local actors, stakeholders, beneficiaries including the researchers myself (Long \& Long, 1992). Theoretical interpretations have appraised how tourism development activities are contributing to rural development. My theoretical reflections show that habitus presences of past experiences of actors (both duty bearers and service providers) have been re/forming community development outcomes due to the contributions of tourism development assets (Thieme, 2006). It is fostering mutual relationships between and among Dalits and Gurung community and transforms social practices (Maton, 2008). Dalits people are applying diversified livelihood practices for improving their social positions based on the capital they have (Jenkins, 2002).

For me, both Dalit and Gurung community members are actively involved in tourism activities to create economic capital through cultural capital. They are collecting basket funds from earning from tourism activities for implementing physical infrastructure development projects. Hence, tourism activities have been creating two forms of capital; social capital which consists of resources based on group membership, and symbolic capital which is the form the different types of capital take once they are perceived and recognized as legitimate (Calhoun, 1999, pp. 69-70). I understood that fostering the capability of duty bearers and service receivers/right holders is becoming the foundation for tourism and rural development. They are applying their functioning and capabilities for achieving community wellbeing (Robeyns, 2003). Owing to the functioning approach they are transforming living conditions and through capabilities they are mounting their freedom of choice on livelihood strategies, working with the community and society for enhancing their well-being (Robeyns, 2003). For sustainability of wellbeing, duty bearers and service receivers are jointly implementing environment-friendly development activities. They are working for sustainable development; a development that meets the needs of the present without compromising the ability of future generations to meet their own needs (WCED, 1987, as cited in Wills, 2005). In this attempt, the community forestry users group and tourism development and management committee are jointly working for managing forest and cultural resources (Hada, 2007).

\section{Model for Strategic Interface}

The interfaces between tourism and rural development demand contextual models that I have developed empirically. This strategic interface model has emphasized on contributions of tourism activities on rural development outcomes from the micro perspective (see in Figure 2). Moreover, this model suggested performing diversified rural tourism activities such as nature tourism, cultural tourism, agro-tourism, food tourism, religious, tourism, Vedic or spiritual tourism as well as adventure and sports tourism through collective efforts of local development stakeholders. This model also suggested some strategic inputs, such as mobilizing local youths in tourism development and management activities and ensuring qualitative outcomes and impact of rural tourism on rural economy in general and rural livelihood in particular. That is possible through reforming the existing socio-cultural and economic structures of the countries by the educated individuals. Hence, my model suggested producing ethical, moral, and responsible youths. It is possible through the establishment of informal education centers at local levels that can crop religious/cultural norms and values. The model further tried to produce skilled and competent youths (human capital) through non-formal education or training centers that can be established locally. They can involve in tourism development, promotional, and management activities for achieving rural development outcomes and impact, sustainably. 
Figure 2. Strategic Interface model for Tourism and Rural Development Tourism

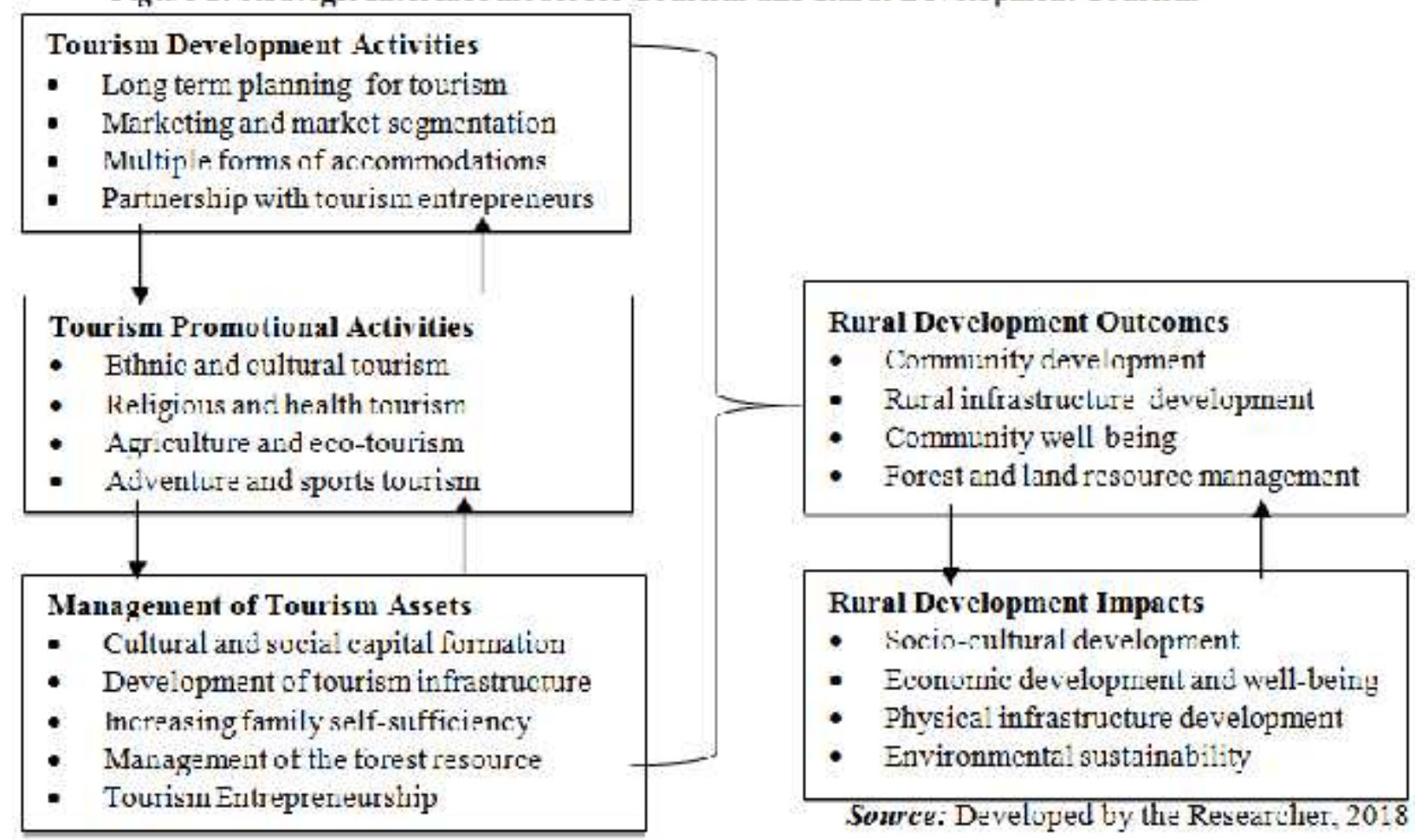

\section{Conclusion}

This study concludes that there is a functional interface between tourism and rural development outcomes. Tourism has brought better rural development outcomes in Sirubari and its peripheral villages. More precisely, while offering tourism activities like; welcome, farewell, sightseeing, and entertainment programs villagers need to manage collectively. It has contributed to developing collectiveness, we feeling, and community sentiment among Dalits and Gurung ethnic groups and established their identity in national and international tourism markets. Moreover homestay becomes a strategy for poverty alleviation as hosts are getting earning and learning opportunities from the guests. Landless people and marginal farmers are also getting farmlands from host community members. Small farmers and role model farmers can supply their products in tourism villages. Hence, tourism not only improves the livelihood of the rural people but transforms the overall status of rural development outcomes. Likewise, tourism is becoming a strategy for physical infrastructure development. Host community members can invest tourism basket funds, local government funds, and community development funds in rural infrastructure development projects. Finally, tourism becomes a strategy for environmental development or biodiversity conservation. With different levels of knowledge, local people understood that natural resources including farmland, greenery forest, and hills and mountains are major attractions for tourism development. Owing to that, villagers are preserving jungle, sites and also performing organic farming practices. Finally, tourism activities in Sirubari not only build social capital, develop rural infrastructures, maintain community well-being, and conserve biodiversity but also become a learning center for others living around Panchmul and beyond.

\section{Key Notes}

[1] The federation, provinces, and local levels shall protect Nepal's independence, sovereignty, territorial integrity, autonomy, national interest, overall development, multi-party competitive democratic republic, and federal governance system, human right/fundamental rights, rule of law, separation of power, and 
check and balance, and equitable society based on plurality and equality and inclusive representative and identity (CAS, 2015).

[2] Interface as an organized entity of interlocking relationships; site for conflict, incompatibility, and negotiation and multiple discourses for knowledge generation process (Long, 1989).

[3] The legislative, executive, judiciary, political parties, social organizations, media, private sectors, and civil society are the local development stakeholders in federal Nepal (CAS, 2015).

[4] The name Panchmul was borrowed from Panchmul, meaning five stone taped natural drinking water sources. According to hearsay, it was the symbol of five Pandava brothers who themselves extracted drinking water during their exile around Panchmul. In recent years, the drinking water project made those taps cemented which are located in the venue of Shree Trisahid Secondary School, Panchmul.

[5] Gurung are living along the southern slope of Annapurna Himalaya in the Western-central region. Most of them join govt. job (British, Indian, Nepal Army, and Police), involved in agriculture and sheep breeding. Rodi cultural institution, Ghatu and Sorati dances are unique cultural practices of Gurung people (Bista, 1967, pp. 91-104).

[6] The highest peak of the hilly range of Panchmul or viewpoint is situated at 2300 meters in height from sea level.

[7] In Nepal, Dalits comprise approximately 14 percent of the population (CBS, 2012). They are divided into two categories, i.e. Hill Dalits and Tarai Dalits. The highest concentrations of Hill Dalits are in Gandaki Province.

[9] The cultural organization of the Gurung people migrated from Sirubari, Bejhang, Majhkateri, and Darau villages of Syangja District.

[9] The whole life activities of the students were divided into four stages (25 years for each); Balashram (child education life), Gristhaashram (marital life), Banprasthasram (traveling life), and Sanyasasram (Spiritual life).

\section{References}

Aandhikhola Rural Municipality [ARM]. (2017). Profile of Aandhikhola rural municipality. Published by Aandhikhola Rural Municipality.

Asian Development Bank [ADB]. (2019). Nepal's economy.https://www.adb.org/countries/nepal/economy. (accessed on 8/03/2019).

Atchoarena, D. (2003). Education for rural development: towards new policy response. UNESCO Publishing International Institute for Educational Planning.

Bennett, L. Sijapati, B. \& Thapa, D. (2013). Gender and social exclusion in Nepal update. Himal Books.

Bista, D. B. (1967). People of Nepal (Reprint in 2013). Ratna Pustak Bhandar.

BK, A. (2013). The stigma of the name: the making and remaking of Dalit identity in Nepal. Social Science Baha.

Boto, I. \&Fotabong, E. (2012). Major drivers for rural transformation in Africa: Resources on rural transformation in Africa, (24). http:// brusselsbriefings.files.wordpress.com/2012/10/br-24-ruraltransformation-in-africa-eng. pdf

Bourdieu, P. (1986). The forms of capital. In J. Richardson, handbook of theory and research for the sociology of education (241-58).

Calhoun, C. (1999). Habitus, field, and capital: The question of historical specificity. In Calhoun et al., (Eds.), Bourdieu: Critical Perspectives(pp. 61-88). Polity Press.

Central Bureau of Statistics [CBS]. (2019). Nepal in figures 2019. Government of Nepal.

Central Bureau of Statistics [CBS]. (2012). Report on poverty in Nepal 2010/11. Government of Nepal.

Nepalese Journal of Development and Rural Studies, Volume, 18, 2021 
Central Bureau of Statistics [CBS]. (2018). Nepal population (1950 - 2018). Government of Nepal.

Chaudhary, P. K. \& Pasa, R. B. (2015). Agriculture education for rural development in Nepal. Journal of Training and Development, 1(1), 39-45.

Constitution Assembly Secretarial [CAS]. (2015). The new constitution of Nepal 2072 BS. Lumbini Pustak Pasal.

Costa, C. A. \&Chalip, L. (2005). Adventure sports tourism in rural revitalization: An ethnographic evaluation. European Sport Management Quarterly, 5(3), 257279. doi:10.1080/16184740500190595

Creswell, J. W. (2007). Qualitative inquiry and research design (2nd ed.). Sage Publication.

Creswell, J. W. (2009). Research design: Qualitative, quantitative, and mix methods approach (3rd ed.). University of Nebraska-Lincoln. Sage Publication.

Denzin, N. K. \& Lincoln, Y. S. (2011). Handbook of qualitative research (4th ed.). Sage Publication.

Department for International Development [DFID]. (2012). Sustainable livelihoods guidance sheets.

Eadington, W. R. \& Smith, V. L. (1992). Introduction: The emergence of alternative forms of tourism. In Smith, V. L. \&Eadington, W. R. (Eds.), Tourism alternatives(pp.1-12). University of Pennsylvania Press.

Flyvbjerg, B. (2011). Case study. In Denzin, N. K. \& Lincoln, Y. S. (2011), Handbook of qualitative research (4th ed.) (301-316). Sage Publication.

Hada, G. B. (2007). Sustainable rural development.Dikshant Pustak Bhandar.

Hall, C. M. (Eds.). (2007). Pro-poor tourism: Who benefits? Channel View Publications.

Harpham, T. Grant, E. \& Thomas, E. (2002). Measuring social capital within health surveys: Key issues. Health Policy and Planning, 17(1), 106-111.

Hettne, B. (1996). Ethnicity and development: Geographical perspective (16-44). London: John Wiley \& Sons Limited.

Hoermann, B. \& Kollmair, M. (2010). Integrated value chain development as a tool for poverty alleviation, in rural mountain areas. International Centre for Integrated Mountain Development.

Homestay Association of Nepal [HOSAN]. (2018). Homestay darpan. Publication of HOSAN.

Jenkins, R. (2002). Pierre Bourdieu. London and New York: Routledge.

Joshi, D. R. (2008). Socio-economic impact of tourism in Nepal order or paradox. In R. P. Upadhyay (Ed.), Reading in Rural Tourism (111-132). Sunlight Publication.

Kunwar, R. R. (2006). Tourists and tourism. International School of Tourism and Hotel Management.

Long, N. \& Long, A. (Eds.) (1992). Battlefields of knowledge: The interlocking of theory and practice in social research and development. Routledge Publication.

Long, N. (Ed.) (1989). Encounters at the interface: A perspective on social discontinuities in rural development. Wageningen Agricultural University.

Maton, K. (2008). Habitus. In M. Grenfell (Ed.), Pierre Bourdieu: Key concepts, (49-65).Rawat Publication.

Ministry of Culture, Tourism and Civil Aviation [MoCTCA]. (2017). National tourism strategic plan (2016-25). Government of Nepal.

Ministry of Culture, Tourism and Civil Aviation [MoCTCA]. (2018). 100 new tourism destinations of Nepal. Planning and Evaluation Division.

Ministry of Federal Affair and General Administration [MoFAGA]. (2017). Local Governance Operation Act, 2074. Government of Nepal

Ministry of Federal Affair and General Administration [MoFAGA]. (2018). Local governance and local government in Nepal. Government of Nepal.

Ministry of Finance (MoF). (2016). Economic survey2015/16 (2072/73). Kathmandu: Government of Nepal. Retrieved from http://www.mof.gov.np

Ministry of Finance [MoF]. (2019). Economic survey 2017/18. Government of Nepal. 
National Dalits Commission [NDC]. (2008). The proposed bill of the national Dalit rights commission. Government of Nepal.

National Planning Commission [NPC]. (2002). Tenth five-year plan (2002-2007). Government of Nepal.

National Planning Commission [NPC]. (2010). Twelfth three-year interim plan (2010/11 2012/13). Government of Nepal.

National Planning Commission [NPC]. (2010). Twelfth three-year interim plan (2010/11 2012/13). Government of Nepal.

National Planning Commission [NPC]. (2016). Annual household survey 2015/16. Government of Nepal.

National Planning Commission [NPC]. (2016). Fourteenth three-year plan (2016/17-2018/19). Government of Nepal.

Nepal National Dalit Social Welfare Organization [NNDSWO]. (2015). Human rights situation of Dalit community in Nepal. A Publication of NNDSWO.

Nepal Tourism Board [NTB]. (2019). Tourism statistics, 2018. A Publication of NTB.

Panchmul Village Development Committee (2015). Profile of Panchmul village development committee. Syangja.

Panchmul Village Development Committee (2015/16). Annual action plan of Panchmul village development committee. Syangja.

Panchmul Village Development Committee (2016). Profile of Panchmul village development committee. Syangja.

Pandey, D. R. (1999). Nepal's failed development: Reflections on the mission and the maladies. Nepal South Asia Centre.

Pasa, R. B. (2019). Interfaces between education, tourism, and rural development (Unpublished Ph.D. Dissertation, Tribhuvan University). Faculty of Education.

Pasa, R. B. (2020). Performance evaluation of Amaltari buffer zone community homestay, Nawalpur. IOSR Journal of Humanities and Social Science (IOSR-JHSS), 25(7, Series 4), 01-10. doi: 10.9790/0837-2507040110

Responsible Ecological Social Tour [REST]. (2003). Community-based tourism: The sustainability challenge.http://www.iadb.org/int/ipn/English/support-files/REST-ENGpdf

Richards, G. (2009). Tourism development trajectories. from culture to creativity. CAB International Publication.

Robeyns, I. (2003). The capability approach: An interdisciplinary introduction.University of Amsterdam.

Sen, A. (1982). Liberty as control: An appraisal. Midwest Studies in Philosophy, 7, 207-221. Philosophy Documentation Center.

Shrestha, N. R. (2009). In the name of development: A reflection on Nepal.Educational Publishing House. Singh, K. (1999). Rural development, principle, policies, and management (2nd ed.). Sage Publication.

Singh, K. (2009). Rural development, principle, policies, and management (3 d eds.). Sage Publication.

Swami, V. (2016). Bhagavad-Gita as it is (9th ed.). Bhaktivedant Book Trust.

Telfer, D. J. \& Sharpley, R. (2008). Tourism and development in the developing world. Taylor \& Francis.

Thieme, S. (2006). Social networks and migration: Far-west Nepalese labor migrants in Delhi. London: Transaction Publishers.

Thomson, P. (2008). Field. In M. Grenfell (Ed.), Pierre Bourdieu: Key concepts, (67-81).Rawat Publications.

Tourism for Rural Poverty Alleviation Program [TRPAP]. (2004). Tourism marketing strategy for Nepal(2005-2020).

Tourism for Rural Poverty Alleviation Program [TRPAP]. (2006). Annual report.http://www.welcomenepal.com/trpap/req/publications_stuffs/ar2003.pdf January

United Nations [UN]. (2015). Post-2015: Farming a new approach to sustainable development. IRF Independent Research Forum. 
United Nations Educational Scientific and Cultural Organization [UNESCO]. (2003). Education for rural development: Towards new policy responses (D. Atchoarena, Ed.). International Institute for Educational Planning.

United Nations Educational, Scientific and Cultural Organization [UNESCO]. (2015). Towards a global common good? Rethinking education. UNESCO Publication.

Upadhyay, R. P. (2008) (Ed.). Case study of rural tourism in Sirubari, Bandipur, and Ghalegaun in readings in rural tourism (305-330). Sunlight Publication.

Wills, K. (2005). Theories and practices of development. Routledge Publication.

World Tourism Organization [WTO]. (1998). Guide for local authorities on developing sustainable tourism.

World Tourism Organization [WTO]. (2010). Framework for the collection publication of tourism statistics. Madrid, Spain.

World Tourism Organization [WTO]. (2015). Annual research key fact: Travel and tourism economic impact.

World Travel and Tourism Council [WTTC]. (2012). Nepal economic impact report.http://www.wttc.org/site media/uploads/downloads/nepal2012.pdf

World Travel and Tourism Council [WTTC]. (2017). Annual research: Key facts. Travel and Tourism Economic Impact.

Yazan, B. (2015). Three approaches to case study methods in education: Yin, Merriam, and Stake. The Qualitative Report, 20(2), 134-152.

Yin, R. K. (2013). Case study research: Design and method (3rd ed.). Sage Publication.

Nepalese Journal of Development and Rural Studies, Volume, 18, 2021 